\title{
Model Tes Keterampilan Dasar dan Kondisi Fisik untuk Mengidentifikasi Bakat Calon Atlet Bolabasket
}

\author{
David Iqroni \\ Universitas Jambi. Jalan Lintas Jambi-Muara Bulian Km. 15, Mendalo Darat, Jambi 36122, Indonesia \\ Email: davidiqroni@ymail.com \\ Received: 4 September 2017; Accepted: 3 October 2017
}

\begin{abstract}
Abstrak
Penelitian ini bertujuan untuk menyusun model keterampilan dasar dan kondisi fisik untuk mengidentifikasi bakat calon pebolabasket yang sahih dan handal berdasarkan karakteristik keberbakatan dalam cabang olahraga bolabasket. Jenis penelitian ini adalah penelitian pengembangan yang mengadaptasi beberapa langkah penelitian yang dikemukakan oleh Borg \& Gall sebagai berikut: (1) studi pendahuluan dan pengumpulan data, (2) perencanaan pelaksanaan penelitian, (3) pengembangan produk awal, (4) uji coba produk awal, (5) revisi untuk menyusun produk utama, (6) uji coba produk utama, (7) revisi untuk menyusun produk operasional, (8) uji coba produk operasional, (9) revisi produk akhir, (10) implementasi produk akhir. Uji coba produk awal dilakukan pada 40 anak. Uji coba produk utama dilakukan pada 124 anak. Uji coba produk operasional sebanyak 402 anak. Hasil penelitian dan pengembangan ini berupa model tes bakat untuk calon atlet bolabasket.. Model tes bakat dinyatakan layak digunakan karena memiliki tingkat validitas dan reliabilitas yang tinggi, dengan nilai $r_{\text {hitung }}$ lebih besar daripada nilai $r_{\text {tabel }}(0,195)$. Model tes bakat calon atlet bolabasket yang berupa skala penilaian (norma) yang dikemas dalam buku pedoman (modul) dapat digunakan sebagai pegangan para pelatih dan guru pendidikan jasmani dalam proses mengidentifikasi calon atlet dengan berbagai tingkat keberbakatan dan model tersebut efektif dan efisien.
\end{abstract}

Kata Kunci: model tes keterampilan dasar dan kondisi fisik, bolabasket.

\section{A Model of Basic Skills and Physical Condition Tests for Identify Candidate Talent Basketball Players}

\begin{abstract}
This study aims to develop a model of basic skills and physical condition to identify prospective talent basketball players which, is valid and reliable based on the characteristics of giftedness in the sport basketball. This research is research and development adapting some measures proposed by Borg and Gall including: (1) preliminary studies and data collection, (2) planning the implementation of the research, (3) the initial product development, (4) initial product trials, (5) a revision to compose the main products, (6) the main product trials, (7) a revision to draft operational products, (8) product testing operations, (9) the revision of the final product, (10) the implementation of the final product. The Initial product trials were conducted to 40 students. The main product trials were conducted to 124 students. Product testing was conducted to 402 students. The results of the research and development is in the form of an aptitude test models for basketball players. The aptitude test model is declared fit for use because it has a high degree of validity and reliability, with a value greater than r-table 0,195. The developed test model for prospective basketball players in the form of a scale of ratings (norm) is packed in the manual. It can be used as a manual for the coaches and physical education teachers in the process of identifying candidates for athletes with different levels of giftedness and the model is effective and efficient.
\end{abstract}

Keywords: model tests of basic skills and physical condition, basketball.

How to Cite: Iqroni, D. (2017). Model tes keterampilan dasar dan kondisi fisik untuk mengidentifikasi bakat calon atlet bolabasket. Jurnal Keolahragaan, 5(2), 142-150. doi:http://dx.doi.org/10.21831/jk.v5i2.15595

Permalink/DOI: http://dx.doi.org/10.21831/jk.v5i2.15595 


\section{PENDAHULUAN}

Proses pembinaan olahraga merupakan suatu prosedur yang harus di laksanakan untuk mencapai prestasi terbaik. Dalam upaya dan usaha tersebut tentu banyak hal yang harus dipertimbangkan, agar setiap tahap dalam proses pembinaan berjalan dengan baik dan benar. Begitu banyak faktor yang mempengaruhi keberhasilan dari sebuah pembinaan olahraga. Ketika satu faktor mengalami permasalahan, tentu faktor lain juga akan terkena dampak mengingat setiap faktor tersebut memiliki interelasi yang kuat. Oleh karena itu, proses pembinaan harus dikelola oleh berbagai pihak yang memiliki kompetensi di bidang olahraga. Hal tersebut tentu akan memperkuat kaidah dan kajian keilmuan secara ilmiah dan mempererat hubungan antara akademisi dan praktisi di bidang olahraga. Berbicara soal pembinaan olahraga, tentu secara khusus ruang lingkup kajian akan membahas perihal olahraga prestasi. Sejauh ini, olahraga prestasi telah mengalami perkembangan yang begitu pesat. Hal ini dikarenakan, olahraga prestasi telah memberikan dampak yang positif bagi seluruh pelaku olahraga. Menurut Rachman (2011, p. 40) dalam kajian keterlaksanaan pendidikan jasmani dan olahraga di DIY, salah satu masalah kritis yang terjadi adalah terlalaikannya pembinaan terhadap domain kognitif (misalnya aspek penalaran dan kemampuan memecahkan masalah dan ranah afektif terutama aspek pendidikan watak (misalnya self-esteem, respect dan responsibility). Dalam ruang lingkup yang lebih luas, prestasi yang diperoleh sebuah negara dalam bidang olahraga tidak hanya sekadar memberikan keuntungan finansial, namun lebih dari itu, sebuah negara yang memperoleh prestasi olahraga juga akan menerima sebuah pengakuan dari negara-negara lain. Tidak bisa dipungkiri bahwa sebuah prestasi olahraga tidak diperoleh secara instan. Begitu banyak faktor yang mempengaruhi, namun semua bersumber pada kemauan seluruh pihak terkait untuk membangun kerjasama yang baik dalam merancang sebuah proses pembinaan olahraga untuk mencapai prestasi yang maksimal. Secara khusus, titik permasalahan terletak pada proses pembinaan calon atlet. Jika berbicara mengenai proses pembinaan prestasi olahraga, tentu tidak akan lepas dari permasalahan tentang pembinaan pada tahap calon atlet. Tahap calon atlet merupakan masa dimana proses awal pembinaan perlu dilaksanakan dengan spesifik. Begitu juga untuk cabang olahraga bolabasket. Seperti diketahui bahwa keberhasilan pencapaian prestasi tidak lepas dari peranan pembinaan calon atlet. Untuk mencapai prestasi tersebut maka diperlukan suatu pembinaan yang berkonsep dari akar. Artinya, pembinaan perlu dilakukan dari dasar secara baik dan benar yang diterapkan secara bertahap, berjenjang, dan berkesinambungan sehingga memilki tujuan yang jelas tentang pencapaian pada tiap jenjang.

Pembinaan calon atlet pada hakekatnya adalah penanaman konsep dasar yang kuat sebagai modal untuk mengembangkan keterampilan yang lebih lanjut untuk menciptakan pemain-pemain berprestasi. Proses pembinaan pemain bolabasket yang berprestasi tidak lepas dari faktor-faktor pendukung seperti: sarana, prasarana, pelatih yang berkualitas, kompetisi yang teratur, program latihan, pemain berbakat dan alat evaluasi dari pelaksanaan program latihan apakah program latihan sesuai dengan harapan atau belum. Khusus di kawasan Daerah Istimewa Yogyakarta, bolabasket bukanlah sebuah olahraga yang terdengar asing. Bahkan terdapat beberapa tempat pembinaan calon atlet bola basket, seperti Assist Basketball School, Samudra Basketball Club dan Smart Basketball. Hal ini menunjukkan bahwa Yogyakarta juga merupakan salah satu dari beberapa basis tumbuh dan berkembangnya permainan bolabasket. Namun, Yogyakarta seakan kehilangan kecemerlangannya dikarenakan ketidakmampuan mempertahankan prestasi di berbagai even bolabasket nasional. Proses pembinaan merupakan faktor yang sebaiknya perlu ditindak lanjuti, mengingat prestasi sebuah tim sangat dipengaruhi oleh proses pembinaan secara keseluruhan. Secara khusus, tindak lanjut perlu dilakukan pada proses pembinaan calon atlet. Hal tersebut menjadi sangat vital dikarenakan sebuah klub akan mengalami proses regenarasi mengingat pemain bolabasket memiliki batas usia tertentu untuk mencapai titik akhir dalam karir perbolabasketan. Tanpa proses pembinaan usia dini yang baik dan benar, prestasi perbolabasketan Yogyakarta akan sulit mengimbangi daerahdaerah lain di Indonesia.

Olson \& Hergenhahn (2009, p. 24) menyatakan bahwa sebuah model berbeda dengan teori, model biasanya tidak dipakai untuk menjelaskan proses yang rumit, model digunakan untuk menyederhanakan proses dan menjadikannya lebih mudah dipahami. Model dipakai untuk menunjukkan bagaimana sesuatu itu seperti sesuatu yang lain. Lebih jelas lagi 


\section{Jurnal Keolahragaan 5 (2), September 2017 - 144}

David Iqroni

dinyatakan bahwa model biasanya digunakan untuk hal-hal yang bersifat menggambarkan sesuatu, menjelaskan suatu proses, mengkaji atau menganalisis sesuatu sistem, menggambarkan suatu kejadian, dan bersifat memprediksi sesuatu keputusan yang akan diambil (Sujiono \& Sujiono, 2010, p. 66).

Menurut Mardapi (2008, p. 67) tes merupakan cara untuk menaksir besarnya kemampuan manusia secara tidak langsung, yakni melalui respons terhadap sejumlah stimulus. Secara khusus, tes memiliki beberapa tujuan penting, antara lain: (1) mengetahui tingkat kemampuan peserta didik, (2) mengukur pertumbuhan dan perkembangan peserta didik, (3) mendiagnosis kesulitan belajar peserta didik, (4) mengetahui hasil belajar dan pengajaran, (5) memotivasi pendidik dan peserta didik dalam proses pembelajaran. Tidak jarang tes digunakan untuk beberapa tujuan, namun tidak akan memiliki keefektifan yang sama untuk semua tujuan.

Bolabasket adalah olahraga berselang yang menggabungkan perubahan cepat dan berulang-ulang dalam arah gerakan. Mobilisasi energi dari awal sampai akhir pertandingan basket berasal dari sumber aerobik, bahkan berpikir kegiatan ini membutuhkan jumlah khusus yang terkait dengan percepatan pendek dan melompat, yang lebih tergantung pada energi aerobik (Metaxas, 2009, p. 134). Untuk dapat bermain bola basket dengan baik maka masing-masing gerakan tersebut harus dipelajari satu persatu, dan selanjutnya perlu adanya koordinasi antara unsur gerak yang satu dengan yang lainnya.

Bola basket mini adalah modifikasi permainan bola basket dewasa yang telah disesuaikan dengan kebutuhan anak baik laki-laki dan perempuan. Mini bolabasket adalah permainan sederhana dan permainan keterampilan bukan kekuatan, anak laki-laki dan anak perempuan dapat bermain bersama. Mini bola basket adalah cara yang ideal untuk memperkenalkan permainan bolabasket untuk anak-anak (Sleap, 1984, p. 22). Permainan bola basket dapat diajarkan sejak dini. Tujuan dari bola basket mini adalah untuk memberikan kesempatan bagi anak-anak untuk mempersiapkan kemampuan yang akan mereka transfer ke dalam permainan bola basket yang sesungguhnya. Menurut Ahmadi (2008, pp. 13$21)$, teknik dasar dalam bermain bolabasket yaitu mengoper bola (passing), menerima bola (catching), menggiring bola (dribbling), menembak (shooting), latihan olah kaki (footwork) dan pivot. Selain pada fisik dan mental yang digunakan dalam bermain bolabasket. Adapun teknik-teknik yang digunakan dalam bermain bolabasket adalah mengoper bola, menerima bola, menggirirng bola, menembak, tembakan melayang, dan memoros

Anak dengan kondisi fisik yang baik mempunyai beberapa keuntungan, diantaranya: atlet mampu dan mudah mempelajari keterampilan yang relatif sulit, tidak mudah lelah saat mengikuti latihan maupun pertandingan, program latihan dapat diselesaikan tanpa mempunyai banyak kendala, serta dapat menyelesaikan tugas yang berat. Kondisi fisik sangat diperlukan oleh seorang atlet. The evolution of athletics means to recognize its importance in people life. How could we treasure today the place that is has in the collective conscience, if we didn't know it's road along mankind (Răchită, 2012, p. 56) Atlet yang tidak mempunyai kondisi fisik yang prima, maka pencapaian prestasi puncak akan mengalami banyak kendala dan mustahil dapat berprestasi tinggi.

Sistem dan pola yang ada pada permainan bolabasket tersebut tentu memerlukan persyaratan fisik agar dapat dilakukan dengan sebaik baiknya. Keadaan atau fisik juga sangat penting serta dibutuhkan dalam permainan bolabasket. Hasil teknik dan taktik pun akan lebih baik apabila di dukung dari kemampuan fisik yang bagus. Dalam setiap latihan fisik selalu bertujuan untuk meningkatkan kualitas fisik yang dasar secara umum dan menyeluruh. Kualitas fisik ditentukan oleh energi dan kebugaran otot. Kebugaran energi yang meliputi system aerobic dan anaerobic, yang laktik maupun alaktik, sedangkan yang dimaksud kebugaran otot adalah keadaan dimana seluruh komponen biomotor yang meliputi ketahanan, kekuatan, kecepatan, power, fleksibilitas, keseimbangan, dan koordinasi, termasuk juga kelincahan. Men's basketball strength and conditioning coaches were also asked about what sources of information were most widely used to increase their professional knowledge (Franciosi, Guidetti, Gallotta, Emerenziani, \& Baldari, 2010, p. 78).

Latihan untuk peningkatan kondisi fisik dalam setiap cabang olahraga pasti berbeda. Hal ini seharusnya disesuaikan dengan kebutuhan gerak, predominan sistem energi, dan lama pertandingan yang digunakan, sehingga latihan fisik akan mendukung penampilan atlet yang berpotensi pada saat pertandingan. Physic exercises and sport activities have exited the interest and fascination of many personalities from many different domains; philosophy, medicine, teaching, arts, and culture (Rachita, 
2012, p.54). Berdasarkan pendapat ahli di atas dapat disimpulkan bahwa, komponen kondisi fisik yang ada antara lain kecepatan, kekuatan, kelincahan, koordinasi, dan daya tahan memiliki pengaruh yang sangat penting bagi pemain bolabasket. Kecepatan, koordinasi, daya tahan, kekuatan, kelentukan dan kelincahan merupakan biomotor yang sangat berperan pada permainan bolabasket. Seorang atlet bolabasket yang memiliki kecepatan bergerak yang cepat akan sangat mudah untuk bermain bolabasket.

Bakat merupakan faktor bawaan yang dimiliki oleh setiap manusia, baik secara fisik maupun mental. Menurut Renzulli (Sternberg \& Davidson, 2005, pp. 256-257) bakat memiliki beberapa karakteristik tertentu, di antaranya kemampuan di atas rata-rata, keberminatan, serta kreativitas. Tentu kadar keberbakatan setiap manusia juga sangat beragam. Karena pada dasarnya setiap manusia yang dilahirkan ke dunia ini pasti memiliki kelebihan dan kekurangan masing-masing. Oleh karena itu, perkembangan bakat sangat dipengaruhi oleh berbagai faktor lingkungan. Identifikasi bakat atau upaya pencarian bibit olahragawan merupakan salah satu tugas seorang guru dan pelatih olahraga. Tugas identifikasi bakat pada dasarnya didasarkan pada pemikiran yang bersifat prakiraan mengenai kemungkinan pencapaian prestasi apabila seseorang sejak dini diberi kegiatan belajar dan berlatih olahraga secara serius. Talent identification refers to the process of recognizing the potential to become an elite player, among a current group of participants. It entails predicting performance over long periods of time by measuring physical, physiological, psychological and sociological attributes as well as technical abilities (Reilly \& Williams, 2005, p. 125). Diperkirakan bahwa anak memungkinkan untuk meraih prestasi yang tinggi di bidang olahraga di kemudian hari, maka tidak salah apabila sejak dini anak yang bersangkutan diarahkan untuk menekuni kegiatan olahraga. Anak berbakat adalah mereka yang diidentifikasi atau ditemukan oleh orangorang profesional, dimana anak tersebut memang mempunyai kemampuan yang sangat menonjol, mampu mencapai prestasi tinggi.

\section{METODE}

\section{Model Pengembangan}

Penelitian ini menggunakan metode Research and Development (Penelitian dan Pengembangan). Research and Development adalah suatu proses atau langkah-langkah untuk mengembangkan suatu produk baru atau menyempurnakan produk yang sudah ada yang dapat dipertanggungjawabkan (Sukmadinata, 2005, p. 164). Pengembangan dilaksanakan untuk mendapatkan sebuah model tes bakat untuk permainan bola basket. Penelitian pengembangan merupakan industri berbasis model pengembangan. Hasil temuan dari penelitian tersebut digunakan untuk merancang produk dan prosedur baru yang selanjutnya secara sistematis diuji di lapangan, dievaluasi, dan disempurnakan. Sehingga produk tersebut memenuhi kriteria efektif, bermutu, atau memenuhi standar serupa.

Prosedur pengembangan dalam penelitian ini mengadaptasi langkah-langkah penelitian dan pengembangan Gall, Gall, \& Borg (2007). Menurut Gall, Gall, \& Borg (2007, p. 589) dalam melaksanakan proses penelitiaan dan pengembangan terdapat 10 (sepuluh) langkah yang harus ditempuh, sebagai berikut: (1) studi pendahuluan dan pengumpulan data (kajian kepustakaan, pengamatan lapangan, membuat kerangka kerja penelitian), (2) perencanaan (merumuskantujuan penelitian, memperkirakan dana dan waktu yang diperlukan, prosedur kerja penelitian, serta berbagai bentuk partisipasi kegiatan selama kegiatan penelitian), (3) mengembangkan produk awal (perancangan draf awal produk), (4) uji coba awal (mencobakan draf produk ke wilayah dan subjek yang terbatas), (5) revisi untuk menyusun produk utama (revisi produk berdasarkan hasil ujicoba awal), (6) uji coba lapangan utama (uji coba terhadap produk hasil revisi ke wilayah dan subjek yang lebih luas), (7) revisi untuk menyusun produk operasional, (8) uji coba produk operasional (uji efektivitas produk), (9) revisi produk akhir dan (10) diseminasi dan implementasi produk hasil pengembangan. Namun, pada penelitian dan pengembangan disederhanakan menjadi 6 (enam) langkah, sebagai berikut: (1) studi pendahuluan dan pengumpulan data, (2) perencanaan proses penelitian dan pengembangan, (3) validasi produk, (4) uji coba produk, (5) revisi produk, dan (6) implementasi produk.

Dalam penelitian ini uji coba produk awal dilakukan sebanyak dua kali, yaitu uji coba skala kecil dan uji coba skala luas. Sebelum dilakukan uji coba di lapangan (uji coba skala kecil dan uji coba skala besar), produk penelitian dibuat berupa draf model model tes bakat untuk permainan bola baket. Selanjutnya divalidasikan terlebih dahulu kepada para pakar yang 


\section{Jurnal Keolahragaan 5 (2), September 2017 - 146}

David Iqroni

telah ditunjuk. Dalam tahap ini para pakar akan memvalidasi serta memberikan masukan dan penilaian terhadap draf model yang telah disusun, sehingga akan diketahui apakah model yang disusun layak untuk diujicobakan di lapangan. Kemudian dalam tahap ujicoba di lapangan, peran dari para pakar serta guru pendidikan jasmani adalah untuk mengobservasi kelayakan draf model yang telah disusun dengan kenyataan di lapangan. Dan setelah ujicoba skala luas selesai dilakukan, maka akan menghasilkan sebuah model pembelajaran yang valid setelah ada revisi dari ujicoba skala luas. Setelah dinyatakan valid dan reliabel kemudian dilakukan proses penerjemahan skor hasil tes menjadi skala penilaian (norma) berdasarkan kriteria tertentu.

Subjek uji coba dalam penelitian ini adalah siswa SD yang berumur 10-11 tahun. Kemudian sesuai dengan tahapan penelitian, maka akan dilakukan beberapa tahapan proses pengambilan data. Dalam penelitian ini dilakukan uji coba lapangan, yaitu uji coba skala kecil dan uji coba skala besar. Jumlah sampel untuk uji coba skala kecil 40 testi, untuk uji coba skala besar berjumlah 124 testi, sedangkan untuk uji norma berjumlah 402 testi.

Data yang dikumpulkan dari penelitian ini merupakan data yang diperoleh dari para ahli (validator) dan subjek penelitian (testi). Data dari para ahli diperoleh dengan menggunakan angket (kuesioner) untuk rancangan produk dengan menilai kualitas model tes keterampilan dasar dan kondisi fisik untuk mengidentifikasi bakat calon atlet bolabasket. Sedangkan data dari testi didapat dari hasil perolehan skor setiap butir tes yang dilakukan dalam rangkaian model tes keterampilan dasar dan kondisi fisik untuk mengidentifikasi bakat calon atlet bolabasket. Penilaian unsur keberbakatan dilakukan sebagai bahan pertimbangan bahwa testi yang digunakan pada proses penelitian dan pengembangan telah memenuhi kriteria sebagai subjek uji coba. Penilaian unsur keterampilan dasar dan kondisi fisik juga digunakan untuk memperkuat asumsi bahwa testi yang mampu menunjukkan kemampuan terbaik dalam berbagai tahapan tes merupakan testi yang dianggap sangat berbakat dan testi yang tidak mampu menunjukkan kemampuan terbaik dalam berbagai tahapan tes merupakan testi yang dianggap sangat tidak berbakat dalam bidang bolabasket

Data yang dikumpulkan dari penelitian ini adalah data kualitatif yang diperoleh dari hasil observasi dan kuesioner serta masukan dari ahli, guru, dan siswa. Data dari pakar dan guru pendidikan jasmani menggunakan angket untuk menilai kualitas model sebelum uji coba di lapangan. Sedangkan uji coba di lapangan dengan skala kecil dan skala besar data yang dihasilkan berasal dari observasi yang diberikan kepada para pakar dan guru pendidikan jasmani saat mengobservasi pelaksanaan uji coba yang telah didokumentasikan dalam wujud buku panduan tes. Sedangkan data dari siswa, didapatkan dari hasil pengisian kuesioner setelah siswa mengikuti atau menjadi subjek uji coba dalam skala luas.

Instrumen dalam penelitian ini adalah angket yang disusun oleh peneliti yang kemudian dijadikan alat penilaian dari pakar dan guru pendidikan jasmani tingkat sekolah dasar. Pakar yang dipilih merupakan pakar dalam bidang bola basket, pakar dalam bidang pendidikan jasmani, pakar dalam bidang olahraga calon atlet. Pada saat uji coba skala besar diambil pula data dengan kuesioner kepada siswa yang menjadi responden atau subjek uji coba. Dengan diketahuinya pendapat dari siswa, maka model yang didapatkan akan lebih baik lagi kualitasnya.

Model tes keterampilan dasar dan kondisi fisik untuk mengidentifikasi bakat untuk calon atlet bolabasket menggunakan sistem sirkuit (circuit) tes. Dalam sirkuit tes tersebut terdapat 6 base (arena tes) yang disusun berdasarkan urutan tingkat tes yang paling mudah hingga tes yang paling sulit. Latar belakang penggunaan sistem sirkuit training tersebut berdasarkan azas keefektifan dan keefisienan baik waktu maupun biaya. Selain itu, sistem sirkuit tes di prediksi akan mudah dimengerti dan dilaksankan oleh para testi.

\section{Model Tes}

Model tes keterampilan dasar dan kondisi fisik untuk mengidentifikasi bakat untuk calon atlet bolabasket menggunakan sistem sirkuit (circuit) tes. Dalam sirkuit tes tersebut terdapat 6 base (arena tes) yang disusun berdasarkan urutan tingkat tes yang paling mudah hingga tes yang paling sulit. Latar belakang penggunaan sistem sirkuit training tersebut berdasarkan azas keefektifan dan keefisienan baik waktu maupun biaya. Selain itu, sistem sirkuit tes di prediksi akan mudah dimengerti dan dilaksankan oleh para testi. Adapun keenam tes tersebut antara lain; Vertical Jump Test, Ball Feeling Test, Wall Pass Test, Shooting Test, Dribble Test, Shuttle Run Test 


\section{Jurnal Keolahragaan 5 (2), September 2017 - 147}

David Iqroni

\section{Analisis Data}

Analisis data merupakan proses mencari dan menyusun secara sistematis data yang diperoleh dari hasil wawancara, catatan lapangan, dan data-data lain, sehingga dapat mudah dipahami, dan temuan tersebut dapat diinformasikan kepada pihak lain. Analisis data dilakukan dengan mengorganisasikan data, menjabarkan ke dalam unit-unit, melakukan sintesa, menyusun ke dalam pola, memilih mana yang penting dan yang akan dipelajari, serta membuat kesimpulan yang dapat disampaikan kepada orang lain (Sugiyono, 2010, p. 244). Teknik analisis data yang digunakan dalam penelitian dan pengembangan ini, sebagai berikut:

Uji Validitas

Uji validitas dilakukan untuk mengetahui tingkat kesahihan data yang ada. Adapun uji validitas yang digunakan pada penelitian dan pengembangan ini yakni, uji validitas isi. Uji validitas isi dilakukan untuk mengestimasi instrumen tes yang dilaksanakan oleh para ahli (expert judgement). Analisis data dilakukan dengan menggunakan inter-items correlations, yakni mengkorelasikan data hasil skor setiap butir tes dengan skor total, menggunakan teknik analisis korelasi product moment dari Pearson. Perhitungan tersebut dilakukan untuk mengetahui koefisien validitas masing-masing butir tes yang disusun. Data yang diperoleh dari setiap butir tes diuji validitasnya dengan menggunakan bantuan program komputer SPSS 22.0 Version IBM.

Uji Reliabilitas

Uji reliabilitas dilakukan untuk menggambarkan konsistensi hasil pengukuran pada uji coba skala besar. Dalam hal ini, pelaksanaan setiap butir tes dilakukan sebanyak 2 (dua) kali. Uji reliabilitas dilakukan dengan menggunakan test-retest Cronbach's Alpha dengan bantuan program komputer SPSS 22.0 Version IBM.

\section{Z Score}

Z Score dilakukan untuk menyamakan satuan dari skor setiap butir tes, sehingga hasil dari setiap butir dapat dijumlahkan, hasil dari penjumlahan ini berupa total skor. Hal ini dilakukan karena skor perolehan setiap butir tes yang terdiri dari berbagai jenis, yakni dalam bentuk frekuensi satuan jumlah dan perolehan satuan waktu. Proses $Z$ Score dilakukan dengan bantuan program komputer SPSS 22.00 Version IBM.

\section{Grading (Penilaian)}

Penilaian dilakukan untuk menerjemahkan skor hasil tes yang telah dikonversikan ke dalam klasifikasi evaluatif menurut karakteristik yang relevan, dengan menggunakan penilaian yang mengacu pada suatu norma (normreferenced evaluation). Grading dipergunakan untuk menentukan skala penilaian (norma) tes. Adapun penilaian yang dipergunakan merupakan penilaian dengan skor standar, yakni dengan mengubah skor hasil tes ke dalam bentuk penyimpangannya dari mean dalam satuan deviasi standar.

\section{Uji Deskriptif}

Uji deskriptif dilakukan untuk menganalisis data dengan cara mendeskripsikan serta menggambarkan data yang telah terkumpul sebagaimana adanya yang bertujuan untuk membuat kesimpulan yang berlaku untuk umum (generalisasi). Statistik deskriptif hanya digunakan untuk mendeskripsikan data hasil penelitian sehingga data tersebut dapat dengan mudah untuk dipahami dan dimengerti secara umum.

\section{HASIL DAN PEMBAHASAN}

\section{Hasil}

Penelitian ini bertujuan untuk menyusun istrumen tes bakat calon atlet bolabasket untuk anak usia 10-11 yang valid dan reliabel. Penelitian ini bersifat penelitian dan pengembangan di mana setiap butir tes merupakan hasil diskusi yang telah dilakukan peneliti, pelatih dan ahli pencarian bakat calon atlet. Bentuk tes dalam penelitian ini mengambil beberapa tes kondisi fisik dan keterampilan dasar yang sudah ada sebelumnya dan menggabungkan beberapa tes yang sesuai dengan cabang olahraga bolabasket kemudian mengembangkan model tes untuk mendapatkan norma yang valid dan reliabel.

Rangkaian buti tes tersebut meliputi: (a) tes tinggi dan berat badan (b) vertical jump test yakni tes untuk mengukur daya ledak otot tungkai, (c) wall pass test yakni tes kemampuan mengoper bola, (d) ball feeling test yakni tes kemampuan mengontrol bola, (e) shooting test yakni tes kemampuan menembak bola, (f) dribbling test yakni tes kemampuan menggiring bola, (g) shuttle run test yakni tes untuk mengukur kelincahan. Setiap butir tes tentu memiliki fungsi yang sangat spesifik. Hal tersebut dilandasi oleh kajian teori mengenai kondisi fisik dan keterampilan dasar bolabasket dengan dan tanpa bola. Mengingat proses penelusuran 


\section{Jurnal Keolahragaan 5 (2), September 2017 - 148}

David Iqroni

bakat (talent detection) merupakan salah satu upaya dan usaha yang harus dilakukan sedini mungkin. Hal tersebut memperkuat asumsi bahwa tes bakat harus di lakukan pada calon atlet. Namun, setiap cabang olahraga tentunya memiliki karakteristik yang beragam. Tentunya perlu dilakukan penyesuain antara kajian teori dan fakta empiris yang terdapat di lapangan, agar produk ini bisa diaplikasikan dengan baik dan benar.

Tabel 1. Validitas Tes

\begin{tabular}{ccc}
\hline Butir Tes & Nilai Koefisien & Keterangan \\
\hline VerticalJump & 0.912 & Valid \\
Ball Feeling & 0.954 & Valid \\
Wall Pass & 0.870 & Valid \\
Shooting & 0.925 & Valid \\
Dribbling & 0.943 & Valid \\
Shuttle Run & 0.899 & Valid \\
\hline
\end{tabular}

Pada Tabel 1 dijabarkan nilai koefisien

Pada tabel di atas dijabarkan hasil tingkat validitas setiap butir tes, antara lain: vertical jump test memiliki nilai validitas sebesar 0,912, ball feeling test memiliki nilai validitas sebesar 0,954, wall pass test memiliki nilai validitas sebesar 0,870, shooting test memiliki nilai validitas sebesar 0,925, Dribbling Test memiliki nilai validitas sebesar 0,943 , dan shuttle run test memiliki nilai validitas sebesar 0,899 , Setiap butir tes dinyatakan valid karena memiliki nilai $\mathrm{r}_{\text {hitung }}$ yang lebih besar dari nilai $r_{\text {tabel }}$ yakni sebesar 0,176 dimana $\mathrm{N}$ (jumlah sampel) sebesar 124 dengan taraf signifikansi sebesar 5\%.

Tabel 2. Reliabilitas Tes

\begin{tabular}{ccc}
\hline Butir Tes & Nilai Koefisien & Keterangan \\
\hline VerticalJump & 0.964 & Reliabel \\
Ball Feeling & 0.986 & Reliabel \\
Wall Pass & 0.978 & Reliabel \\
Shooting & 0.943 & Reliabel \\
Dribbling & 0.933 & Reliabel \\
Shuttle Run & 0.866 & Reliabel \\
\hline
\end{tabular}

Pada Tabel 2 dijabarkan hasil tingkat reliabilitas setiap butir tes, antara lain: vertical jump test memiliki nilai reliabilitas sebesar 0,964, ball feeling test memiliki nilai reliabilitas sebesar 0,986, wall pass test memiliki nilai reliabilitas sebesar 0,978 , shooting test memiliki nilai reliabilitas sebesar 0,943 , dribbling test memiliki nilai reliabilitas sebesar 0,903 , dan shuttle run test memiliki nilai reliabilitas sebesar 0,866 . Setiap butir tes dinyatakan reliabel karena memiliki nilai $r_{\text {hitung }}$ yang lebih besar dari nilai $\mathrm{r}_{\text {tabel }}$ yakni sebesar 0,176 dimana $\mathrm{N}$ (jumlah sampel) sebesar 124 dengan taraf signifikansi sebesar $5 \%$.

Tabel 3. Skala Penilaian (Norma) Tes

\begin{tabular}{ccc}
\hline Butir Tes & Nilai & Norma \\
\hline & 5 & $\geq 40$ \\
Vertical Jump Test & 4 & $37-39$ \\
& 3 & $34-36$ \\
& 2 & $34-36$ \\
Butir Tes & 1 & $\leq 30$ \\
\hline & Nilai & Norma \\
\hline Ball Feeling Test & 5 & $\geq 52$ \\
& 4 & $48-51$ \\
& 3 & $44-47$ \\
Butir Tes & 2 & $40-43$ \\
& 1 & $\leq 39$ \\
\hline Wall Pass Test & Nilai & Norma \\
\hline & 5 & $\geq 23$ \\
& 3 & $21-22$ \\
& 2 & $19-20$ \\
& 1 & $\leq 16$ \\
\hline
\end{tabular}

\begin{tabular}{ccc}
\hline Butir Tes & Nilai & Norma \\
\hline & 5 & $\geq 6$ \\
Shooting Test & 4 & 5 \\
& 3 & 4 \\
& 2 & 3 \\
Butir Tes & Nilai & Norma \\
\hline & 5 & $\leq 12.18$ \\
Dribbling Test & 4 & $12.19-12.99$ \\
& 3 & $13.00-13.78$ \\
& 2 & $13.79-14.59$ \\
Butir Tes & 1 & $\geq 14.60$ \\
\hline & Nilai & Norma \\
\hline Shuttle Run Test & 5 & $\leq 8.30$ \\
& 4 & $8.31-9.09$ \\
& 3 & $9.10-9.88$ \\
& 2 & $9.89-10.67$ \\
& 1 & $\geq 10.68$ \\
\hline
\end{tabular}

Dari Tabel 3 dapat dijabarkan bahwa dari hasil uji coba massal (produk operasional) diperoleh data, sebagai berikut: pada butir vertical jump test memiliki skala penilaian (norma) sebagai berikut: nilai 5 jika memperoleh skor $\geq 40$, nilai 4 jika memperoleh skor 37-39, nilai 3 jika memperoleh skor 34-36, nilai 2 jika memperoleh skor 31-33, dan nilai 1 jika memperoleh skor $\leq 30$. Pada butir ball feeling test memiliki skala penilaian (norma) sebagai berikut: nilai 5 jika memperoleh skor $\geq 52$, nilai 4 jika memperoleh skor 48-51, nilai 3 jika memperoleh skor 44-47, nilai 2 jika memperoleh skor 40-43, dan nilai 1 jika memperoleh skor $\leq 39$. Pada butir wall pass test memiliki skala penilaian (norma) sebagai berikut: nilai 5 jika memperoleh skor $\geq$ 
23, nilai 4 jika memperoleh skor 21-22, nilai 3 jika memperoleh skor 19-20, nilai 2 jika memperoleh skor 13,44-14,06, dan nilai 1 jika memperoleh skor $\geq 14,07$. Pada butir shooting test memiliki skala penilaian (norma) sebagai berikut: nilai 5 jika memperoleh skor $\geq 6$, nilai 4 jika memperoleh skor 5 , nilai 4 jika memperoleh skor 4, nilai 2 jika memperoleh skor 3, dan nilai 1 jika memperoleh skor $\leq 2$. Pada butir dribbling test memiliki skala penilaian (norma) sebagai berikut: nilai 5 jika memperoleh skor $\leq 12,18$, nilai 4 jika memperoleh skor 12,19-12,99, nilai 3 jika memperoleh skor $13,00-13,78$, nilai 2 jika memperoleh skor 13,79-14,59, dan nilai 1 jika memperoleh skor $\geq 14,60$. Pada butir shuttle run test memiliki skala penilaian (norma) sebagai berikut: nilai 5 jika memperoleh skor $\leq 8,30$, nilai 4 jika memperoleh skor $8,31-9,09$, nilai 3 jika memperoleh skor $9,10-9,88$, nilai 2 jika memperoleh skor 9,89-10,67, dan nilai 1 jika memperoleh skor $\geq 10,68$.

Tabel 4. Klasifikasi Skala Penilaian Tes

\begin{tabular}{cc}
\hline Rentang & Klasifikasi \\
\hline$\geq 24$ & Sangat Berbakat \\
$20-23$ & Berbakat \\
$16-19$ & Cukup Berbakat \\
$12-15$ & Tidak Berbakat \\
$\leq 11$ & Sangat Tidak Berbakat \\
\hline
\end{tabular}

Dari Tabel 4 dapat dijabarkan bahwa dari hasil uji coba massal (produk operasional) diperoleh data, sebagai berikut: pada skala penilaian $\geq 24$ diperoleh 58 siswa dengan klasifikasi sangat berbakat (A), pada skala penilaian 20-23 diperoleh 149 siswa dengan klasifikasi berbakat (B), pada skala penilaian 16-19 diperoleh 32 siswa dengan klasifikasi cukup berbakat (C), pada skala penilaian 12-15 diperoleh 122 siswa dengan klasifikasi tidak berbakat (D), dan pada skala penilaian $\leq 11$ diperoleh 41 siswa dengan klasifikasi sangat tidak berbakat (E)..

\section{Pembahasan}

Sebuah proses penelitian dan pengembangan dapat dilakukan apabila terdapat data hasil analisis kebutuhan berdasarkan fakta empiris yang ditemukan di lapangan. Penelitian dan pengembangan model tes bakat calon atlet bolabasket menggunakan model deskriptif prosedural, dimana tes menggariskan langkah pelaksanaan penelitian dan pengembangan yang harus dilaksanakan secara bertahap dan berurutan untuk menghasilkan sebuah produk yang siap pakai.
Tahapan paling dasar yang harus dilakukan untuk merancang sebuah model tes yakni konseptualisasi permasalahan. Selanjutnya apabila konseptualisme permasalahan telah dilaksanakan, maka pengembangan rancangan produk dapat segera dilakukan. Setlanjutnya apabila pengembangan rancangan produk telak dilakukan, maka tahap uji coba dapat segera dimulai, dalam beberapa tahapan uji coba. Langkah tersebut dipergunakan untuk mengembangkan sebuah model dengan harapan akan memperoleh instrumen tes yang valid dan reliabel, yakni dengan melibatkan peran para ahli (expert judgement) dalam bidang bolabasket serta tes dan pengukuran olahraga.

Instrumen tes bakat calon atlet bolabasket mengacu pada proses focus group discussion yang dilakukan bersama dengan para pelatih bolabasket dan guru penjaskes SD kelas atas. Selanjutnya hasil diskusi tersebut di validasi oleh para ahli untuk diolah menjadi sebuah desain produk awal (draft) yang siap untuk diuji cobakan pada uji coba skala kecil. Adapun model tes bakat calon atlet bolabasket mengacu pada tes yang sudah ada, namun belum memiliki skala penilaian (norma) yang sesuai dengan sasaran produk akhir.

Berdasarkan dari deskripsi data dan hasil data dapat di hasilkan suatu pembahasan sebagai berikut: hasil dari data yang diperoleh, kemudian diolah oleh peneliti untuk menghasilkan suatu model bakat untuk calon atlet bolabasket yang meliputi: (1) tes vertical jump; (2) tes ball feeling; (3) tes wall pass; (4) tes shooting; (5) tes dribbling; (6) tes shuttle run.

Setelah dilakukan uji coba produk pada skala kecil, dilakukan revisi produk untuk memperbaiki segala bentuk kekurangan dan kelemahan yang diperoleh dari hasil uji coba skala kecil berupa analisis hasil video rekaman pelaksanaan tes secara keseluruhan. Setelah direvisi, maka produk siap digunakan pada tahap uji coba selanjutnya, yakni pada uji coba skala besar. Adapun tujuan dilakukannya uji coba skala besar, yakni untuk menentukan tingkat validitas dan reliabilitas tes serta menyusun skala penilaian (norma) tes. Selanjutnya setelah tes dinyatakan valid dan reliabel serta telah memiliki skala penilaian, maka dilakukan proses penyusunan produk akhir yang dikemas dalam buku panduan (modul) serta video tutorial pelaksanaan tes (CD). Setelah produk akhir selesai disusun, maka selanjutnya dilakukan proses implementtasi produk pada pusat pembinaan sepakbola 
usia dini di kawasan Daerah Istimewa Yogyakarta.

Keterbatasan Penelitian

Penelitian dan pengembangan ini juga tidak terlepas dari beberapa keterbatasan, adapun keterbatasan tersebut, antara lain: (1) keterbatasan biaya yang mengakibatkan jumlah subjek penelitian (testi) yang terbilang masih relatif kecil, (2) testi tidak jarang mengalami cidera ringan yang mengakibatkan sedikit terganggunya proses pengambilan data di lapangan, dan (3) keadaan cuaca yang tidak mendukung (hujan) yang mengakibatkan sedikit tertundanya proses pengambilan data di lapangan.

\section{SIMPULAN}

Model tes keterampilan dasar dan kondisi fisik untuk mengidentifikasi bakat calon atlet bolabasket dinyatakan valid berdasarkan hasil uji coba skala besar (produk utama). Dengan rincian sebagai berikut: vertical jump test memiliki nilai validitas sebesar 0,912 , ball feeling test memiliki nilai validitas sebesar 0,954 , wall pass test memiliki nilai validitas sebesar 0,870 , shooting test memiliki nilai validitas sebesar 0,925, Dribbling Test memiliki nilai validitas sebesar 0,943, dan shuttle run test memiliki nilai validitas sebesar 0,899 , Setiap butir tes dinyatakan valid karena memiliki nilai $r_{\text {hitung }}$ yang lebih besar dari nilai $r_{\text {tabel }}$ yakni sebesar 0,176 dimana $\mathrm{N}$ (jumlah sampel) sebesar 124 dengan taraf signifikansi sebesar 5\%.

\section{DAFTAR PUSTAKA}

Ahmadi, N. (2008). Permainan bola basket. Surakarta: Era Intermedia.

Franciosi, E., Guidetti, L., Gallotta, M. C., Emerenziani, G. Pietro, \& Baldari, C. (2010). Contributions of Selected Fundamental Factors to Basketball Performance in Adult Players with Mental Retardation. The Journal of Strength \& Conditioning Research, 24(8). Retrieved from http://journals.lww.com/nscajscr/Fulltext/2010/08000/Contributions_of _Selected_Fundamental_Factors_to.27.as px
Gall, M. D., Gall, J. P., \& Borg, W. R. (2007). Educational research: An introduction. Boston: Pearson/Allyn \& Bacon.

Mardapi, D. (2008). Teknik penyusunan instrumen tes dan nontes. Yogyakarta: Mitrs Cendikia Offset.

Metaxas, T. (2009). Place marketing, strategic planning and competitiveness: The case of Malta. European Planning Studies, 17(9), 1357-1378. https://doi.org/10.1080/096543109030535 39

Olson, M. H., \& Hergenhahn, B. R. (2009). An introduction to theories of learning. Pearson/Prentice Hall.

Răchită, C. I. (2012). The management of practicing basketball games in physical education and sports lessons to develop personality. Review of International Comparative Management, 13(1). Retrieved from http://www.rmci.ase.ro/no13vol1/12.pdf

Rachman, H. A. (2011). Keterlaksanaan pendidikan jasmani dan olahraga di Daerah Istimewa Yogyakarta. Jurnal Pendidikan Jasmani Indonesia, 8(1). Retrieved from https://journal.uny.ac.id/index.php/jpji/arti cle/view/3482

Reilly, T., \& Williams, A. M. (2005). Science and soccer. London: Routledge.

Sleap, M. (1984). Mini sport. Heinemann Educational.

Sternberg, R. J., \& Davidson, J. E. (2005). Conceptions of giftedness. Cambridge University Press.

Sugiyono. (2010). Metode penelitian pendidikan: Pendekatan kuantitatif, kualitatif, dan $R \& D$. Bandung: Alfabeta.

Sujiono, Y. N., \& Sujiono, B. (2010). Bermain kreatif berbasis kecerdasan jamak. Jakarta: Indeks.

Sukmadinata, N. S. (2005). Landasan psikologi proses pendidikan. Bandung: Remaja Rosdakarya. 